\title{
Association Between Serum Uric Acid Levels and Progression of Coronary Artery Calcification in Asian Population
}

Yuki Ohmoto-Sekine ( $\square$ yoomoto@toranomon.gr.jp )

Toranomon Hospital Health Management Center

Makiko Ishihara

Toranomon Hospital Imaging Center

Kazuhisa Amakawa

Toranomon Hospital Health Management Center

Yumiko Ohike

Toranomon Hospital Health Management Center

Yasuji Arase

Toranomon Hospital Health Management Center

\section{Research Article}

Keywords: Atherosclerosis, Coronary artery calcium progression, Hyperuricemia, Risk factor

Posted Date: January 13th, 2021

DOl: https://doi.org/10.21203/rs.3.rs-139520/v1

License: (9) This work is licensed under a Creative Commons Attribution 4.0 International License. Read Full License 


\section{Abstract}

Background: Coronary artery calcium (CAC) is associated coronary heart disease risk. In addition, CAC progression is associated with worsening coronary atherosclerosis and predicts future cardiac events. We aimed to investigate risk factors for the progression of CAC in an asymptomatic Japanese population using low dose computed tomography (CT) lung cancer screening performed during routine health checkup.

Methods: The risk factors for CAC progression were analyzed in 771 asymptomatic subjects who underwent repeated CAC measurement.

Results: Of the 771 subjects, 632 (82.0\%) were males with a mean age of 56 years old, $208(27.0 \%)$ had a history of hypertension, 299 (38.8\%) had dyslipidemia, 81 (10.5\%) had diabetes mellitus, and 180 (23.3\%) had hyperuricemia. During observation, 103 (13.4\%) subjects had CAC progression, while 515 subjects $(66.8 \%)$ showed no calcification. On multivariate analysis, increasing uric acid level was significantly associated with the progression of CAC (odds ratio 1.203, 95\% confidence interval 1.045-1.387, $P=$ $0.010)$.

Conclusions: The results of this study show that hyperuricemia is associated with CAC progression in asymptomatic Japanese subjects.

\section{Background}

Arteriosclerosis is a cause of ischemic heart disease in many patients. It is important, therefore, to identify factors associated with the progression of arteriosclerosis to prevent ischemic heart disease. Coronary artery calcium (CAC) measured by computed tomography (CT) correlates with the amount of coronary atherosclerotic plaque, is a noninvasive technique to evaluate the severity of coronary atherosclerosis, and has been used to predict future coronary events.[1-5] Furthermore, progression of coronary atherosclerosis has been studied using CAC progression in longitudinal studies.[6-8]

A previous study showed age, sex, diabetes, and dyslipidemia to be risk factors for atherosclerotic diseases, in addition to the CAC score.[5] However, it is still unknown whether these risk factors assessed in cross-sectional studies have the same influence on progression of coronary atherosclerosis as factors assessed in longitudinal studies. Thus, we aimed to investigate risk factors of coronary atherosclerosis progression, measured as CAC progression, in an asymptomatic Japanese population using low dose CT lung cancer screening performed during a routine health checkup.

\section{Methods}

\section{Study population}


The study included 2124 asymptomatic subjects who voluntarily underwent CT scan for lung cancer screening at a general health checkup in Toranomon Hospital Health Management Center between April 2010 and December 2012 at baseline. Of these subjects, 836 had at least two visits at our institution. Of these 836 subjects, 65 were excluded from the study for the following reasons: 56 subjects had a history of coronary artery disease, 7 had a pacemaker or valve implantation that could cause artifacts, and 2 had no records of a calcium score. A total of 771 subjects were included in the final analysis. The average time between CT scans was $3.1 \pm 0.9$ years. Medical histories and current medications were derived from medical questionnaires. Hypertension was defined as systolic blood pressure (SBP) $\geq 140 \mathrm{mmHg}$ or diastolic blood pressure (DBP) $\geq 90 \mathrm{mmHg}$ without medication in the outpatient clinic on at least two separate measurements or antihypertensive medication use. Diabetes mellitus was defined as fasting blood glucose $\geq 126 \mathrm{mg} / \mathrm{dL}, \mathrm{HbA} 1 \mathrm{c} \geq 6.5 \%$, or use of medication for diabetes. Dyslipidemia was defined as total cholesterol $\geq 240 \mathrm{mg} / \mathrm{dL}$, low-density lipoprotein (LDL) cholesterol $\geq 140 \mathrm{mg} / \mathrm{dL}$, triglyceride $(T G) \geq 150 \mathrm{mg} / \mathrm{dL}$, high-density lipoprotein (HDL) cholesterol $<40 \mathrm{mg} / \mathrm{dL}$, or previous use of lipidlowering medication. Hyperuricemia was defined as uric acid $\geq 7.1 \mathrm{mg} / \mathrm{dL}$. Obesity was defined as a body mass index $(\mathrm{BMI}) \geq 25 \mathrm{~kg} / \mathrm{m}^{2}$, according to the criteria in the World Health Organization (WHO) Asia-Pacific guidelines.[9] Metabolic syndrome was classified using the NCEP/ATP-III recommendations. [10] Smoking habits (never, former, and current) were obtained from a self-completed questionnaire. The institutional review boards (IRB) at our hospital (Toranomon Hospital IRB [IRB 1175]) approved the study, informed consent was obtained from all subjects, and the study was performed in accordance with the declaration of Helsinki.

\section{Cac Scoring Assessment And Definition Of Progression Of Cac}

All subjects underwent lung cancer screening with a multidetector CT system (Acquilion 64; Toshiba Medical Systems, Tochigi, Japan). CT scans were acquired during one deep inspiratory breath hold, without use of contrast medium or ECG-gating. Low dose lung CT scan was performed using a tube voltage of $120 \mathrm{kV}$, a tube current of $60-70 \mathrm{~mA}$ and 30-35 mAs based on the body size of the subject, and a 300-400 mm field of view. The technical parameters for lung cancer screening CT and reconstruction of images for CAC scoring have been documented previously.[11] In brief, the image was reconstructed using non-overlapping $3.0 \mathrm{~mm}$ slices with a $260-\mathrm{mm}$ field of view, which is the standard method used in clinical practice based on electron beam CT.[12] Use of slice thickness and overlapping reconstruction have a major influence on CAC scoring;[13] thus we used the same reconstruction protocol as that used for cardiac CT for CAC scoring. CAC scores were calculated quantitatively according to the methods by Agatston et al. [14]

We defined the progression of CAC into three groups. No calcification observed during follow up was defined as 0 calcification (group A). Using the percentage methods, CAC progression was defined as an annual percentage change $\geq 15 \%$ at follow up in some studies. $[15,16]$ Considering of definite CAC 
progression, we defined annual percentage change $\geq 20 \%$ at follow up as severe progression (group C), and $<20 \%$ change at follow up was defined as no or mild progression (group B).

\section{Statistical analysis}

Data are expressed as mean \pm standard deviation for continuous variables, and as frequencies and percentages for categorical variables. The significance of differences in quantitative data was determined by the Mann-Whitney U-test and Kruskal Wallis test. Ordered logistic regression analysis was applied to determine which factors were associated with the progression of CAC ( 0 CAC, no or mild CAC progression, and severe CAC progression). Statistical analyses were performed using SPSS for Windows, ver. 13.0 (Chicago, IL, USA), with $P<0.05$ considered significant.

\section{Results}

\section{Clinical characteristics of the subjects}

The characteristics of subjects are shown in Table 1. (Please insert Table 1 here.) Of the 771subjects, 632 (82.0\%) were males with a mean age of 56 years old, 208 (27.0\%) had a history of hypertension, 299 (38.8\%) had dyslipidemia, 81 (10.5\%) had diabetes mellitus, and $180(23.3 \%)$ had hyperuricemia. There were 515 subjects $(66.8 \%)$ in group A, $153(19.8 \%)$ in group B, and $103(13.4 \%)$ in group C. Compared to group $A$, subjects in group $C$ were older and more likely to be male. Risk factors including renal function disorder (creatinine, estimate glomerular filtration rate (eGFR)) and uric acid level were significantly higher in group $\mathrm{C}$ than groups A and B. Total cholesterol, LDL cholesterol, HDL cholesterol, smoking habit, and alcohol intake were not significantly different among the three groups. 
Table 1

Characteristics of the study participants

\begin{tabular}{|c|c|c|c|c|}
\hline & $\begin{array}{l}\text { Group A } \\
(n=515)\end{array}$ & $\begin{array}{l}\text { Group B } \\
(n=153)\end{array}$ & $\begin{array}{l}\text { Group C } \\
(n=103)\end{array}$ & $\begin{array}{l}P \\
\text { value }\end{array}$ \\
\hline Age (years) & $\begin{array}{l}53.2 \pm \\
9.4\end{array}$ & $\begin{array}{l}61.4 \pm \\
9.5\end{array}$ & $\begin{array}{l}61.9 \pm \\
9.1\end{array}$ & $\begin{array}{l}< \\
0.001\end{array}$ \\
\hline Sex (male, \%) & $\begin{array}{l}404 \\
(78.4)\end{array}$ & $\begin{array}{l}134 \\
(87.6)\end{array}$ & $94(91.3)$ & 0.001 \\
\hline Body mass index $\left(\mathrm{kg} / \mathrm{m}^{2}\right)$ & $\begin{array}{l}23.4 \pm \\
3.1\end{array}$ & $\begin{array}{l}23.6 \pm \\
2.9\end{array}$ & $\begin{array}{l}24.3 \pm \\
3.0\end{array}$ & 0.013 \\
\hline Abdominal circumference $(\mathrm{cm})$ & $\begin{array}{l}83.7 \pm \\
9.0\end{array}$ & $\begin{array}{l}85.2 \pm \\
8.2\end{array}$ & $\begin{array}{l}87.0 \pm \\
8.6\end{array}$ & 0.001 \\
\hline Systolic blood pressure $(\mathrm{mmHg})$ & $\begin{array}{l}120.1 \pm \\
13.3\end{array}$ & $\begin{array}{l}123.5 \pm \\
14.2\end{array}$ & $\begin{array}{l}124.7 \pm \\
12.2\end{array}$ & $\begin{array}{l}<.001 \\
0.001\end{array}$ \\
\hline Diastolic blood pressure $(\mathrm{mmHg})$ & $\begin{array}{l}77.1 \pm \\
9.0\end{array}$ & $\begin{array}{l}78.4 \pm \\
8.9\end{array}$ & $\begin{array}{l}79.2 \pm \\
8.6\end{array}$ & 0.067 \\
\hline Fasting blood glucose (mg/dL) & $\begin{array}{l}102.3 \pm \\
15.3\end{array}$ & $\begin{array}{l}103.7 \pm \\
13.6\end{array}$ & $\begin{array}{l}112.1 \pm \\
32.1\end{array}$ & $\begin{array}{l}<.001 \\
0.001\end{array}$ \\
\hline $\mathrm{HbA1c}(\%)$ & $5.4 \pm 0.5$ & $5.5 \pm 0.6$ & $5.6 \pm 0.8$ & $\begin{array}{l}< \\
0.001\end{array}$ \\
\hline Total cholesterol (mg/dL) & $\begin{array}{l}204.8 \pm \\
32.2\end{array}$ & $\begin{array}{l}210.7 \pm \\
33.2\end{array}$ & $\begin{array}{l}206.2 \pm \\
33.9\end{array}$ & 0.158 \\
\hline LDL cholesterol (mg/dL) & $\begin{array}{l}118.7 \pm \\
29.1\end{array}$ & $\begin{array}{l}121.2 \pm \\
28.5\end{array}$ & $\begin{array}{l}117.9 \pm \\
32.8\end{array}$ & 0.458 \\
\hline HDL cholesterol (mg/dL) & $\begin{array}{l}56.6 \pm \\
14.9\end{array}$ & $\begin{array}{l}54.2 \pm \\
14.9\end{array}$ & $\begin{array}{l}54.2 \pm \\
13.7\end{array}$ & 0.103 \\
\hline Triglycerides $(\mathrm{mg} / \mathrm{dL})$ & $\begin{array}{l}116.6 \pm \\
69.1\end{array}$ & $\begin{array}{l}135.7 \pm \\
95.3\end{array}$ & $\begin{array}{l}133.1 \pm \\
85.5\end{array}$ & 0.046 \\
\hline $\mathrm{L} / \mathrm{H}$ ratio & $\begin{array}{l}2.24 \pm \\
0.80\end{array}$ & $\begin{array}{l}2.36 \pm \\
0.70\end{array}$ & $\begin{array}{l}2.30 \pm \\
0.80\end{array}$ & 0.096 \\
\hline Creatinine (mg/dL) & $\begin{array}{l}0.79 \pm \\
0.19\end{array}$ & $\begin{array}{l}0.80 \pm \\
0.15\end{array}$ & $\begin{array}{l}0.93 \pm \\
1.06\end{array}$ & 0.045 \\
\hline eGFR $\left(\mathrm{ml} / \mathrm{min} / 1.73 \mathrm{~m}^{2}\right)$ & $\begin{array}{l}78.8 \pm \\
14.3\end{array}$ & $\begin{array}{l}76.0 \pm \\
12.5\end{array}$ & $\begin{array}{l}73.4 \pm \\
15.3\end{array}$ & $\begin{array}{l}< \\
0.001\end{array}$ \\
\hline Uric acid $(\mathrm{mg} / \mathrm{dL})$ & $\begin{array}{l}5.85 \pm \\
1.32\end{array}$ & $\begin{array}{l}6.04 \pm \\
1.34\end{array}$ & $\begin{array}{l}6.21 \pm \\
1.24\end{array}$ & 0.007 \\
\hline
\end{tabular}

Data are shown as the mean and (SD) or percentages. HbA1c, glycated hemoglobin; LDL, low-density lipoprotein; HDL, high-density lipoprotein; L/H ratio, LDL/HDL ratio; LDL, eGFR, estimated glomerular filtration rate; CKD, chronic kidney disease; SD, standard deviation 


\begin{tabular}{|c|c|c|c|c|}
\hline & $\begin{array}{l}\text { Group A } \\
(n=515)\end{array}$ & $\begin{array}{l}\text { Group B } \\
(n=153)\end{array}$ & $\begin{array}{l}\text { Group C } \\
(n=103)\end{array}$ & $\begin{array}{l}P \\
\text { value }\end{array}$ \\
\hline Hypertension (n, \%) & $\begin{array}{l}115 \\
(22.3)\end{array}$ & $46(30.1)$ & $47(45.6)$ & $\grave{0.001}$ \\
\hline Diabetes (n, \%) & $45(8.7)$ & $14(9.2)$ & $22(21.4)$ & $<.001$ \\
\hline Dyslipidemia (n, \%) & $\begin{array}{l}175 \\
(34.0)\end{array}$ & $73(47.7)$ & $51(49.5)$ & $\iota_{0.001}$ \\
\hline \multicolumn{5}{|l|}{ Smoking history (n, \%) } \\
\hline current & $\begin{array}{l}179 \\
(35.1)\end{array}$ & $45(30.2)$ & 38 (37.3) & 0.441 \\
\hline including former & $\begin{array}{l}363 \\
(70.5)\end{array}$ & $\begin{array}{l}112 \\
(73.2)\end{array}$ & $81(76.6)$ & 0.229 \\
\hline CKD $\left(\right.$ eGFR $\left.<60 \mathrm{ml} / \mathrm{min} / 1.73 \mathrm{~m}^{2}\right)(\mathrm{n}, \%)$ & $31(6.0)$ & $12(7.8)$ & $16(15.5)$ & 0.004 \\
\hline Hyperuricemia $(\mathrm{n}, \%)$ & $\begin{array}{l}102 \\
(19.8)\end{array}$ & $40(26.1)$ & $38(36.9)$ & $\stackrel{<}{<.001}$ \\
\hline Metabolic syndrome & $86(16.7)$ & $33(21.6)$ & $27(26.2)$ & 0.052 \\
\hline Alcohol intake ( $\geq 20$ g/day) (n, \%) & $\begin{array}{l}157 \\
(30.5)\end{array}$ & $40(26.1)$ & $38(36.9)$ & 0.308 \\
\hline $\begin{array}{l}\text { Mean number of constituent factors for metabolic } \\
\text { syndrome }(n, \%)\end{array}$ & $1.1 \pm 1.2$ & $1.5 \pm 1.3$ & $1.8 \pm 1.2$ & $<.001$ \\
\hline
\end{tabular}

\section{Risk Factors Associated With Severe Progression Of Cac}

Univariate regression analyses were performed to determine factors affecting progression of CAC. (Please insert Table 2 here.) The progression of CAC was associated with conventional risk factors with the exception of total cholesterol, LDL cholesterol, smoking habit, and alcohol intake. 
Table 2

Results of the univariate analysis of risk factors for CAC progression

\begin{tabular}{|c|c|c|c|c|}
\hline Variable & Risk ratio & $95 \%$ & $\mathrm{Cl}$ & $P$ value \\
\hline & & lower limit & upper limit & \\
\hline Age (/1 year) & 1.090 & 1.452 & 3.552 & $<0.001$ \\
\hline Sex (male/female) & 2.262 & 1.452 & 1.109 & $<0.001$ \\
\hline Body mass index $\left(/ 1 \mathrm{~kg} / \mathrm{m}^{2}\right)$ & 1.051 & 1.002 & 1.102 & 0.040 \\
\hline Abdominal circumference $(/ 1 \mathrm{~cm})$ & 1.032 & 1.015 & 1.050 & $<0.001$ \\
\hline Systolic blood pressure $(/ 1 \mathrm{mmHg})$ & 1.021 & 1.010 & 1.033 & $<0.001$ \\
\hline Diastolic blood pressure (/1 mmHg) & 1.020 & 1.003 & 1.037 & 0.018 \\
\hline Fasting blood glucose (/1 mg/dL) & 1.018 & 1.009 & 1.027 & $<0.001$ \\
\hline $\mathrm{HbA1c}(/ 1 \%)$ & 1.864 & 1.436 & 2.421 & $<0.001$ \\
\hline Total cholesterol (/1 mg/dL) & 1.003 & 0.999 & 1.008 & 0.159 \\
\hline LDL cholesterol (/1 mg/dL) & 1.001 & 0.996 & 1.006 & 0.730 \\
\hline HDL cholesterol (/1 mg/dL) & 0.989 & 0.979 & 0.999 & 0.037 \\
\hline Triglyceride (/1 mg/dL) & 1.003 & 1.001 & 1.004 & 0.006 \\
\hline eGFR $\left(\mathrm{ml} / \mathrm{min} / 1.73 \mathrm{~m}^{2}\right)$ & 0.979 & 0.969 & 0.990 & $<0.001$ \\
\hline Uric acid (/1 mg/dL) & 1.167 & 1.042 & 1.306 & 0.007 \\
\hline Hypertension $(y / n)^{*}$ & 2.116 & 1.540 & 2.907 & $<0.001$ \\
\hline Diabetes mellitus $(\mathrm{y} / \mathrm{n})^{\star}$ & 1.970 & 1.263 & 3.070 & 0.003 \\
\hline Dyslipidemia $(\mathrm{y} / \mathrm{n})^{*}$ & 1.794 & 1.331 & 2.418 & $<0.001$ \\
\hline Hyperuricemia $(y / n)^{\star}$ & 1.856 & 1.332 & 2.586 & $<0.001$ \\
\hline $\operatorname{CKD}\left(\geq 60 /<60 \mathrm{ml} / \mathrm{min} / 1.73 \mathrm{~m}^{2}\right)$ & 2.125 & 1.281 & 3.526 & 0.004 \\
\hline Metabolic syndrome (ATP III) (y/n) & 1.551 & 1.083 & 2.221 & 0.017 \\
\hline The number of risk factors for METS(/1) & 1.346 & 1.119 & 1.512 & $<0.001$ \\
\hline Smoking history (current, ex / no) & 1.311 & 0.936 & 1.837 & 0.115 \\
\hline Alcohol ( $\geq 20 /<20$ g/day) & 0.480 & 0.206 & 1.121 & 0.090 \\
\hline
\end{tabular}


The results of multivariate analysis of clinical parameters associated with progression of CAC score are shown in Table 3. The multivariate model was adjusted for age, sex, abdominal circumference, systolic blood pressure, triglyceride level, hemoglobin A1c level, eGFR, and uric acid level. On multivariate analysis, high uric acid level was significantly associated with progression of CAC (odds ratio 1.203, 95\% confidence interval 1.045-1.387, $P=0.010$ ). (Please insert Table 3 here.)

Table 3

Results of the ordered logistic regression analysis of risk factors for CAC progression

\begin{tabular}{|lllll|}
\hline Variable & Risk ratio & $\mathbf{9 5 \%}$ & $\mathrm{Cl}$ & $P$ value \\
\hline & & lower limit & upper limit & \\
\hline Age (/1 year) & 1.111 & 1.088 & 1.134 & $<0.001$ \\
\hline Sex (male/female) & 2.719 & 1.618 & 4.570 & $<0.001$ \\
\hline Uric acid $(/ 1 \mathrm{mg} / \mathrm{dL})$ & 1.203 & 1.045 & 1.387 & 0.010 \\
\hline Triglyceride $(/ 1 \mathrm{mg} / \mathrm{dL})$ & 1.002 & 1.000 & 1.004 & 0.030 \\
\hline *Cl, confidence interval; CAC, coronary artery calcium & \\
\hline
\end{tabular}

\section{Discussion}

This is the first study showing that hyperuricemia is a risk factor for CAC progression in asymptomatic Japanese subjects. There are some published studies evaluating the risk factors for CAC progression. From the MESA study, standard coronary risk factors including age, sex, race, smoking, BMI, blood pressure, and diabetes mellitus correlated with both high CAC score and progression.[8] Another studies showed that fatty liver [17] and metabolic syndrome [18] were associated with CAC progression. And recent study from China showed the association between uric acid and CAC progression in young adults with originally zero CAC [19]. Considering about the relationship between uric acid and coronary artery disease, Sun et al studied about the relationship between uric acid and coronary atherosclerosis [20], and Lv et al showed it among young adults less than 35 years of age [21]. But there are still limited number of studies which are evaluated the relationship between uric acid and CAC. Mostly many studies had not been analyzed the association with uric acid and CAC. In this study, we investigated risk factors including not only traditional coronary risk factors but also uric acid level. We found hyperuricemia to be associated with CAC progression.

Although it has been hypothesized that uric acid provides an antioxidant defense in humans, previous clinical and epidemiological studies suggested that elevated uric acid levels are associated with cardiovascular diseases. Several publications demonstrated the association between serum uric acid levels and cardiovascular disorders, including hypertension, [22-24] coronary artery disease, [25-27] and carotid artery atherosclerosis.[28] The potential mechanisms of the association between hyperuricemia and cardiovascular diseases are related to xanthine oxidase and urate transporters. Higher concentration 
of uric acid may reflect high levels of xanthine oxidase activity and oxidative stress. The action of xanthine oxidase leads to generation of superoxide anions and is one of the principle sources of reactive oxygen species (ROS) in the human vasculature. [29,30] Allopurinol is rapidly metabolized to ozypurinol, an analogue of xanthine that preferentially binds to xanthine oxidase, thereby inhibiting its activity.[31] A recent study revealed that urate transporters, which have a major role in renal regulation of urate excretion, are expressed in smooth muscle cells. In case of hyperuricemia, urate transporters may allow uric acid to enter human vascular smooth muscle cells. [32,33] As a result, the renin angiotensin system pathway is activated and NO synthesis is inhibited, causing endothelial dysfunction and cardiovascular diseases.

This study has several limitations. First, the study was retrospective and subjects were self-referred, which may have caused a selection bias compared to population-based participants. In addition, subjects were enrolled based on repeated participation in health screening examinations, and subjects who did not undergo a second CT scan were excluded. Second, use of lung cancer screening CT may also be a limitation, because the CAC score using this method tends to be lower than that that using ECG-gated CT. $[11,34,35]$ The main reason for the lower score may be the radiation dose used in lung cancer screening $\mathrm{CT}$, which is lower than that that used in ECG-gated CT. However, a recent meta-analysis by Xie et al. [34] showed that CAC score categories correlated well between ECG-gated CT and lung cancer screening CT, although the values were still slightly lower than in ECG gated CT. Third, the follow up duration may not be sufficient to evaluate CAC progression. More long-term follow up studies are warranted.

\section{Conclusions}

Our study showed that CAC progressed in one-third of subjects and hyperuricemia was a risk factor for CAC progression in this asymptomatic Japanese population.

\section{Abbreviations}

$\mathrm{BMI}$

body mass index; $\mathrm{CAC}$ :coronary artery calcium; CT:computed tomography; DBP:diastolic blood pressure; ECG:electrocardiogram; eGFR:estimated glomerular filtration rate; HbA1c:glycated hemoglobin; HDL:highdensity lipoprotein; IRB:institutional review board; LDL:Iow-density lipoprotein; MESA Multi-Ethnic Study of Atherosclerosis; NCEP/ATP-III:National Cholesterol Education Program Adult Treatment Panel III; NO:nitric oxide; ROS:reactive oxygen species; SBP:systolic blood pressure; TG:triglyceride; WHO:World Health Organization

\section{Declarations}

\section{Ethics approval and consent to participate}


The institutional review boards (IRB) at our hospital (Toranomon Hospital IRB [IRB 1175]) approved the study, and informed consent was obtained from all subjects.

\section{Consent for publication}

Not applicable.

\section{Availability of data and materials}

The datasets used and/or analyzed during the current study are available from the corresponding author on reasonable request.

\section{Competing interests}

The authors declare that they have no competing interests.

\section{Funding}

This research received no grant from any funding agency in the public, commercial, or not-for-profit sectors.

\section{Authors' contributions}

YOS conceived of the study, set the study design, collected data, analyzed and interpreted the data, and was a major contributor in writing the manuscript. MI, KA and $\mathrm{YO}$ collected data, analyzed and interpreted the data.

YA oversaw the study assessments. All authors oversaw, contributed and approved the final manuscripts.

\section{Acknowledgement}

We would like to thank all study participants.

\section{Authors' information (optional)}

\section{References}

1. Detrano R, Guerci AD, Carr JJ, Bild DE, Burke G, Folsom AR, et al. Coronary calcium as a predictor of coronary events in four racial or ethnic groups. N Engl J Med. 2008;358:1336-45.

2. Budoff MJ, Shaw LJ, Liu ST, Weinstein SR, Mosler TP, Tseng PH, et al. Long-term prognosis associated with coronary calcification: observations from a registry of 25,253 patients. J Am Coll Cardiol. 2007;49:1860-70.

3. Polonsky TS, McClelland RL, Jorgensen NW, Bild DE, Burke GL, Gierco AD, et al. Coronary artery calcium score and risk classification for coronary heart disease prediction. JAMA. 2010; 303:1610- 
6.

4. Greenland P, LaBree L, Azen SP, Doherty TM, Detrano RC. Coronary artery calcium score combined with Framingham score for risk prediction in asymptomatic individuals. JAMA. 2004; 291:210-5.

5. Arad Y, Goodman KJ, Roth M, Newstein D, Guerci AD. Coronary calcification, coronary disease risk factors, C-reactive protein, and atherosclerotic cardiovascular disease events: the St. Francis Heart Study. J Am Coll Cardiol. 2005; 46:158-65.

6. McEvoy JW, Blaha MJ, Defilippis AP, Budoff MJ, Nasir K, Blumenthal RS, et al. Coronary artery calcium progression: an important clinical measurement? A review of published reports. J Am Coll Cardiol. 2010; 56:1613-22.

7. Budoff MJ, Young R, Lopez VA, Kronmal RA, Nasir K, Blumenthal RS, et al. Progression of coronary calcium and incident coronary heart disease events: MESA (Multi-Ethnic Study of Atherosclerosis). J Am Coll Cardiol. 2013; 61:1231-9.

8. Kronmal RA, McClelland RL, Detrano R, Shea S, Lima JA, Cushman M, et al. Risk factors for the progression of coronary artery calcification in asymptomatic subjects: results from the Multi-Ethnic Study of Atherosclerosis (MESA). Circulation. 2007; 115:2722-30.

9. WHO West Pacific Region. The Asia-Pacific perspective: redefining obesity and its treatment. 2000. http://www.wpro.who.int/nutrition/documents/docs/Redefiningobesity.pdf. Accessed

10. Expert Panel on Detection, Evaluation, and Treatment of High Blood Cholesterol in Adults. Executive Summary of the Third Report of the National Cholesterol Education Program (NCEP) Expert panel on Detection, Evaluation, and Treatment of High Blood Cholesterol in Adults (Adult Treatment Panel III). JAMA. 2001; 285:2486-97.

11. Ohmoto-Sekine $Y$, Ishihara $M$, Amakawa $K$, Hsieh SD, Okuda $C$, Hashimoto $M$, et al. Reconstruction of lung cancer screening CT images for measurement of coronary calcium scores: comparison with coronary calcium scores from ECG-gated cardiac CT. Ningen Dock Int. 2014;2:9-13.

12. Horiguchi J, Shen Y, Akiyama Y, Hirai N, Sasaki K, Ishifuro M, et al. Electron beam CT versus 16MDCT on the variability of repeated coronary artery calcium measurements in a variable heart rate phantom. AJR Am J Roentgenol. 2005; 185:995-1000.

13. Ohnesorge B, Flohr T, Fischbach R, Kopp AF, Knez A, Schröder S, et al. Reproducibility of coronary calcium quantification in repeat examinations with retrospectively ECG-gated multisection spiral CT. Eur Radiol. 2002; 12:1532-40.

14. Agatston AS, Janowitz WR, Hildner FJ Zusmer NR, Viamonte M Jr, Detrano R. Quantification of coronary artery calcium using ultrafast computed tomography. J Am Coll Cardiol. 1990; 15:827-32.

15. Raggi P, Callister TQ, Shaw LJ. Progression of coronary artery calcium and risk of first myocardial infarction in patients receiving cholesterol-lowering therapy. Arterioscler Thromb Vasc Biol. 2004; 24:1272-7.

16. Budoff MJ, Hokanson JE, Nasir K, Shaw LJ, Kinney GL, Chow D, et al. Progression of coronary artery calcium predicts all-cause mortality. JACC Cardiovasc Imaging. 2010; 3:1229-36. 
17. Sinn DH, Kang D, Chang Y, Ryu S, Gu S, Kim H, et al. Non-alcoholic fatty liver disease and progression of coronary artery calcium score: a retrospective cohort study. Gut. 2017; 66:323-9.

18. Kim LK, Yoon JW, Lee DH, Kim KM, Choi SH, Park KS, et al. Impact of metabolic syndrome on the progression of coronary calcium and of coronary artery disease assessed by repeated cardiac computed tomography scans. Cardiovasc Diabetol. 2016; 15:92.

19. Shen YW, Wu YJ, Hung YC, Hsiao CC, Chan SH, Mar GY, et al. Natural course of coronary artery calcium progression in Asian population with an initial score of zero. BMC Cardiovasc Disord. 2020; 14:101.

20. Yujiao Sun, Xin Yu, Ying Zhi, Song Geng, Hua Li, Ting Liu, et al. A cross-sectional analysis of the relationship between uric acid and coronary atherosclerosis in patients with suspected coronary artery disease in China. BMC Cardiovasc Disord. 2020; 20:212.

21. Sai Lvt, Wei Liut, Yujie Zhou*, Yuyang Liu, Dongmei Shi, Yingxin Zhao, et al. Hyperuricemia and smoking in young adults suspected coronary artery disase $\leqq 35$ years of age; a hospital-based observational study. BMC Cardiovasc Disord. 2018; 18:178.

22. Sundström J, Sullivan L, D’Agostino RB, Levy D, Kannel WB, Vasan RS. Relations of serum uric acid to longitudinal blood pressure tracking and hypertension incidence. Hypertension. 2005; 45:28-33.

23. Mellen PB, Bleyer AJ, Erlinger TP, Evans GW, Nieto J, Wagenknecht LE, et al. Serum uric acid predicts incident hypertension in a biethnic cohort: the atherosclerosis risk in communities study. Hypertension. 2006; 48:1037-42.

24. Zhang W, Sun K, Yang Y, Zhang, H, Hu FB, Hui R. Plasma uric acid and hypertension in a Chinese community: prospective study and metanalysis. Clin Chem. 2009; 55:2026-34.

25. Liese AD, Hense HW, Lowel H, Doring A, Tietze M, Keil U. Association of serum uric acid with all-cause and cardiovascular disease mortality and incident myocardial infarction in the MONICA Augsburg cohort. World Health Organization Monitoring Trends and Determinants in Cardiovascular Diseases. Epidemiology. 1999; 10:391-7.

26. Choi HK, Curhan G. Independent impact of gout on mortality and risk for coronary heart disease. Circulation. 2007; 116:894-900.

27. Mitsuhashi T, Hibi K, Kosuge M, Morita S, Komura N, Kusama I, et al. Relation between hyperinsulinemia and nonculprit plaque characteristics in nondiabetic patients with acute coronary syndromes. JACC Cardiovasc Imaging. 2011; 4:392-401.

28. Neogi T, Ellison RC, Hunt S, Terkeltaub R, Felson DT, Zhang Y. Serum uric acid is associated with carotid plaques: The National Heart, Lung, and Blood Institute Family Heart Study. J Rheumatol. 2009; 36:378-84.

29. Berry C, Hamilton CA, Brosnan MJ, Magill FG, Berg GA, McMurray JJ, et al. Investigation into the sources of superoxide in human blood vessels: angiotensin II increases superoxide production in human internal mammary arteries. Circulation. 2000; 101:2206-12.

30. Hellsten-Westing Y. Immunohistochemical localization of xanthine oxidase in human cardiac and skeletal muscle. Histochemistry. 1993; 100:215-22. 
31. Elion GB. Enzymatic and metabolic studies with allopurinol. Ann Rheum Dis. 1966; 25:608-14.

32. Price KL, Sautin YY, Long DA, Zhang L, Miyazaki H, Mu W, et al. Human vascular smooth muscle cells express a urate transporter. J Am Soc Nephrol. 2006; 17:1791-5.

33. Nakanishi T, Ohya K, Shimada S, Anzai N, Tamai I. Functional cooperation of URAT1 (SLC22A12) and URATV1 (SLC2A9) in renal reabsorption of urate. Nephrol Dial Transplant. 2013; 28:603-11.

34. Xie X, Zhao Y, de Bock GH, de Jong PA, Mali WP, Oudkerk M, et al. Validation and prognosis of coronary artery calcium scoring in nontriggered thoracic computed tomography: systematic review and meta-analysis. Circ Cardiovasc Imaging. 2013; 6:514-21.

35. Budoff MJ, Nasir K, Kinney GL, Hokanson JE, Barr RG, Steiner R, et al. Coronary artery and thoracic calcium on noncontrast thoracic CT scans: comparison of ungated and gated examinations in patients from the COPD Gene cohort. J Cardiovasc Comput Tomogr. 2011; 5:113-8. 